\title{
POTASSIUM ALKALINE MAGMATISM IN THE RUSSIAN FAR EAST
}

\section{Romashkin A.I.}

Far Eastern Regional Information Computing Centre, Far Eastern Institute for Mineral Resources, Ministry of Natural Resources of the Russian Federation, 31, Gerasimov St., Khabarovsk 680021, Russia

Potassium alkaline magmatism (PAM) is widespread in the Russian Far East having a complicated geological structure and a long evolution. It has manifested itself in all the first order structuralformational zones (SFZ) ranging in age from Upper Proterozoic through Cenozoic (Fig.). However, its mineral composition, petrogeochemistry, metallogeny and P-T-X conditions of its formation have been insufficiently studied.

\begin{tabular}{|c|c|c|c|c|c|c|c|c|c|}
\hline & 1 & II & IIII. & IV & $v$ & VI & VII & VIII-a & VIII-b \\
\hline$N$ & & & & 1 & & & & 2 & 3 \\
\hline$p$ & & & & & & & & 4 & $5 ; 6$ \\
\hline$K_{2}$ & & & & - & & & & & 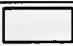 \\
\hline$K_{1}$ & & & & 7 & & 8 & & 9 & 10 \\
\hline $\mathrm{J}$ & & & & & & & & & 11 \\
\hline$T$ & & & & & & & & & \\
\hline $\mathrm{PZ}_{3}$ & & & & 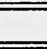 & & & & & \\
\hline $\mathrm{PZ}_{2}$ & & & & & 12 & & 13 & & \\
\hline$P Z_{1}$ & & & & & 14 & & & & \\
\hline $\mathrm{PR}_{2}$ & 15 & & & & & & & & \\
\hline
\end{tabular}

Fig. Geological-structural position and age of the potassium alkaline magmatism in the Russian Far East.

I-Siberian Platform, II-Aldan Shield, III-Stanovaya fold-block system, IV-Bureinsk Massif, VKhankaisk Massif, VI-Yuzhno-Verkhoyanskaya SFZ, VII-Amur-Okhotsk SFZ, VIII-Sikhote-Alinsk SFZ: a-Badzhalo-Gorinsk part, b-Primorsk part. (1-15 - correspond to ordinal numbers in the Table)

The most widespread PAM bodies are dikes and volcanic pipes; stock-like subvolcanic bodies, small nappes and sills have been more scarcely observed. Local showings and small amounts of magmatic products are characteristic features of PAM recognized in the Ingili (Romashkin, 1994), Jiakun'sk (Romashkin, Kukhtina, 1994), Kurung-Uryakhsk (Shnai et al., 1991), Galamsk (Arkhipov, Panskikh, 1975) and other locations.

PAM forms in relation to geodynamic regime of tectonic-magmatic activization or rifting. Generally it is confined to fault zones mainly of north-eastward and sublatitudinal trends referred to the category of inferred faults. In a number of places it is located at the deep faults' intersection nodes.

The PAM showings established in the region belong to intermediate, mafic and ultramafic rocks of sub-alkaline and alkaline rows. In $\mathrm{SiO}_{2} / \mathrm{MgO}-\mathrm{K}_{2} \mathrm{O} / \mathrm{Na}_{2} \mathrm{O}$ diagram the figurative points of some of their representatives are located within the fields typical of kimberlites and lamproites. In some instances they are characterized by increased and high $\mathrm{Ti}, \mathrm{P}, \mathrm{CO}_{2}$, and $\mathrm{H}_{2} \mathrm{O}$ contents (Table). 


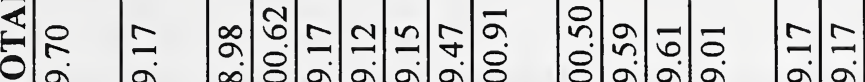

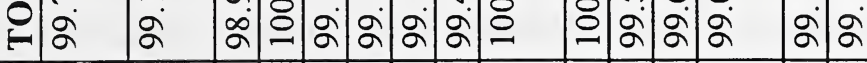

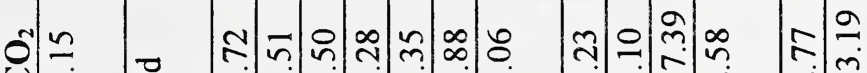

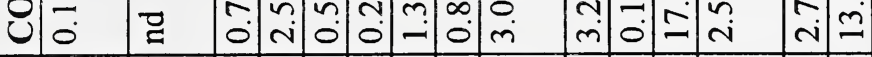

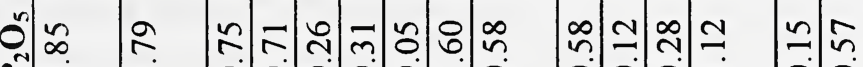

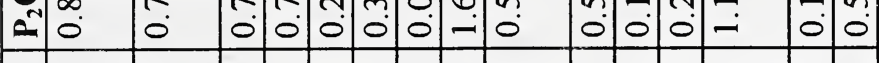

$\doteq$

이 भ

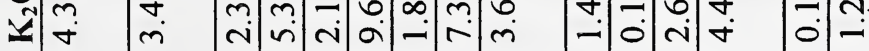

유

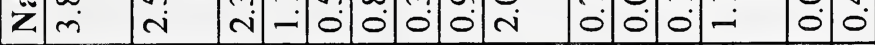

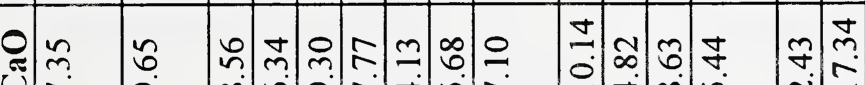

音

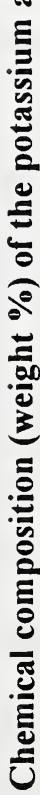

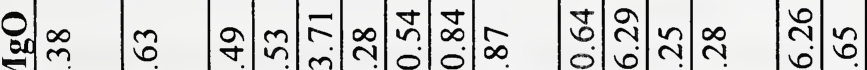

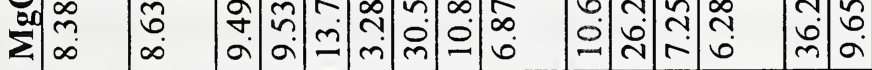

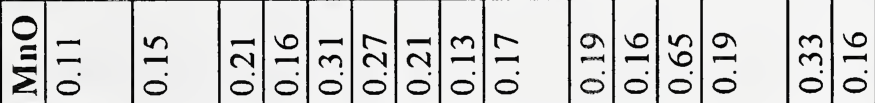

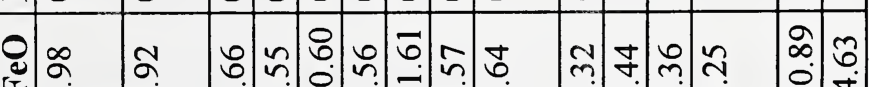

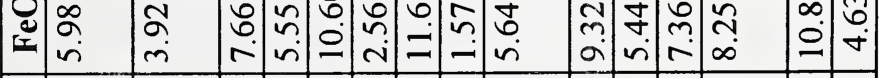

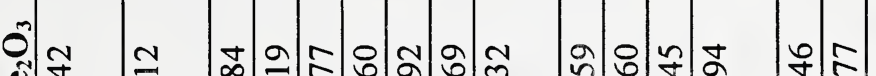

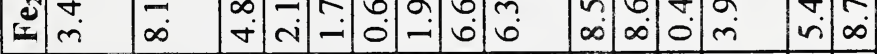

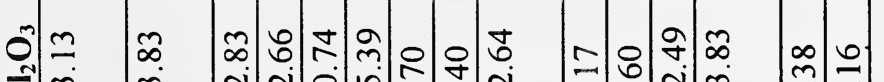

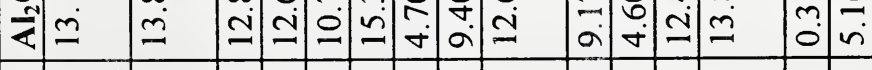

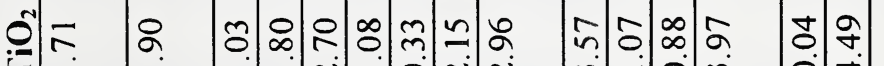

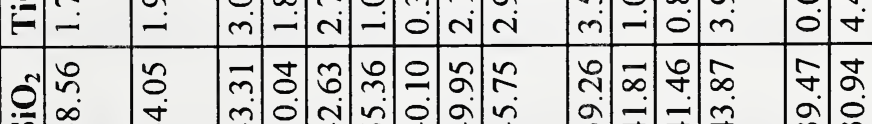

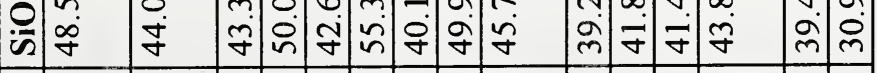

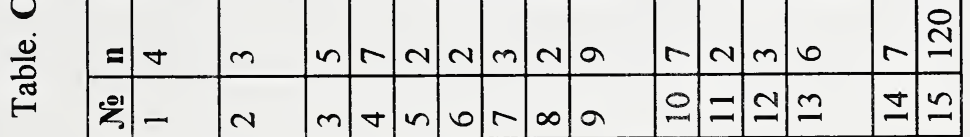

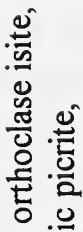
的兽 을 항 咅立 若 语 흐 $+.0$ 㩆 흥응 ㅎ? 的 . 둥ㅎ․ 긍 음 的它

氜 善系 os . 递 드 कo 党.

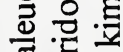
过 0. 疍哭 1 름든 i 은 舫 它 的 政.

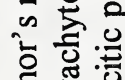
焉 运 을 ชั 
Among the PAM products there can be identified massive varieties, eruptive breccias and autolithic breccias. Porphyritic structures are common. As a rule, the rocks contain variable amounts of olivine, clinopyroxene, phlogopite, biotite, plagioclase, potassium feldspar, amphibole, and leucite of several generations. Accessories are represented by ilmenite, chromite, magnetite, sphene, zircon, apatite, and corundum. Epigenetic alterations are common. Xenoliths of olivinite, pyroxenite, picrite, trachybasalt and metamorphic rocks are present.Garnet peridotite and eclogite have not been observed. Temperature conditions for the PAM formation range from 920 to $1280^{\circ} \mathrm{C}$, pressure from 10 to $40 \mathrm{kbar}$.

The PAM showings occurring in various SFZ have specific chemical compositions. At the same time, the most high-potassium products of various-age magmatism recognized within the same SFZ frequently have some common features in the chemical composition. Due to this, every finding of this rock type deserves detailed studying with the aim of determining their possible relationship with kimberlites or lamproites.

Petrochemical analysis of the PAM observed in the Russian Far East has shown that by the present moment there have not been found any typical representatives of diamond-bearing kimberlites or lamproites. However, in the history of the regional evolution there have been distinguished a number of epochs such as Late Paleogene, Cretaceous, Middle Paleozoic, and Late Proterozoic in relation with which such magmatism is likely to be recognized. Besides, a probable diamond-bearing of some regional PAM representatives possessing certain similarities with kimberlites and lamproites cannot be excluded, though they have been insufficiently studied as regards their probable diamond-bearing.

\section{REFERENCES}

Arkhipov G.I., Panskikh Ye.A., 1975, Questions on magmatism and tectonics in the Far East. Vladivostok, FEB of the USSR Academy of Sciences, p. 56-67.

Govorov I.N., 1977, Geochemistry of ore regions in Primoriye. Moscow, Nauka, 251 p.

Govorov I.N., Blagodareva N.S., Zhuravlev D.Z., 1997, Tikhookeanskaya Geologiya, v. 16, № 5, p. 60-69.

Gurulev Yu.T., Matyunin A.P., Sakhno V.G. et al., 1995, Tikhookeanskaya Geologiya, v.14 № 5, p. 103-108.

Mikhnevich A.A., 1989, Magmatism of ore regions and nodes in Primorie. Vladivostok, p. 92-97.

Prikhodko V.S., Bekhtold A.F., Berdnikov N.V., 1985, Deep petrology of active continental margins. Moscow, Nauka, $152 \mathrm{p}$.

Romashkin A.I., 1994, Tikhookeanskaya Geologiya, v. 13, № 5, p. 82-92.

Romashkin A.I., 1997, Geology and Geophysics, № 2, p. 504-513.

Romashkin A.I., Kukhtina L.M., 1992, Proceedings of DALNEDRA Association, v.2, Khabarovsk, Dalnedra, p. 42-49.

Romashkin A.I., Kukhtina L.M., Lobov A.I., 1996, Tikhookeanskaya Geologiya, v.15, № 2, p. 3339.

Shnai G.K., Sobolev A.Ye., Igoshina I.I., 1991, Doklady of the USSR Academy of Sciences, v. 319, № 4, p. 957-961. 